\title{
Residual and Technical Tax Efficiency Scores for Brazilian Municipalities: a Two-Stage Approach
}

\author{
Maria da Conceição Sampaio de Sousa \\ Professora do Departamento de Economia, Universidade de Brasília (UnB) - Campus Darcy Ribeiro \\ Universidade de Brasília - Caixa Postal 4320, CEP: 70910-900, Brasília - DF. \\ E-mail: csampaiodesousa@gmail.com
}

\section{Pedro Lucas da Cruz Pereira Araújo}

Doutorando em Economia, Universidade de Brasília (UnB) - Campus Darcy Ribeiro

Universidade de Brasília - DF - Caixa Postal: 4320 - CEP: 70910-900

E-mail: araujo.pedrolucas@gmail.com

\section{Maria Eduarda Tannuri-Pianto}

Professora do Departamento de Economia, Universidade de Brasília (UnB) - Campus Darcy Ribeiro, Universidade de Brasília, Caixa Postal, 4320 - CEP: 70910-900 - Brasília - DF.

E-mail: maria.tannuri@gmail.com

Recebido em 05 de março de 2010. Aceito em 25 de outubro de 2011.

\section{Introduction}

Recurrent fiscal imbalances in terms of tax and expenditure assignments among central and local governments are a critical issue in public finance. To equalize tax capacities, cope with spillovers or to achieve national policy objectives, central governments often provide transfers to lower levels of government. These transfers may affect the incentives to improve fiscal performance because they may induce low tax effort in the regions (Litvack, Ahmad and Bird, 1998; Boadway et al., 1999).

This point is particularly relevant for Brazil, as the Constitution of 1988 assured a substantial financial autonomy for subnational governments by increasing the share of public resources accruing to states and municipalities. However, this revenue decentralization was not followed by a decentralization of responsibilities as no conditions were imposed concerning the use of the shared revenues. Concerning this "incomplete fiscal decentralization", where spending authority is devolved to the subnational level while financing relies 
on transfers from the central government, two points deserve to be noticed. Firstly, the lack of tax capacity and managerial abilities for most of the municipalities and secondly, inflated municipalities' expenditures to match their increasing revenues. Additionally, the proliferation of small cities without any fiscal viability and no reliable human resources led to significant imbalances that were transferred to the federal level (Rezende, 1995; Varsano and Mora, 2001).

To cope with the deterioration of municipal finances, a complex system of federal and state transfers set apart expenditure decisions from tax capacity in local jurisdictions as the provision of local public goods rely heavily on those transfers. In this scenario, the reduced productivity of local tax bases can be partly explained by their low tax effort, since it is less costly to obtain resources through transfers from other spheres of government than to exploit their own tax base. Even a greater reliance on property taxes has not increased the much required degree of fiscal autonomy at the local level. However, this dissociation between municipalities' financing needs and their revenues cannot go on indefinitely.

The upsurge of municipal expenses, brought about by the decentralization of public spending granted by the 1988 Constitution and a higher urbanization, together with the fiscal strain faced by the higher levels of government threaten the perpetuation of the current model. For that reason, in recent years, there is an increasing emphasis on the necessity to increase municipalities' tax capacity and the efficiency of tax collection. Hence, tax efficiency measurements are relevant for implementing a sound tax system.

Traditionally, tax effort is computed as a ratio between the observed tax collection and its potential, where the latter comes from regression analysis or stochastic frontiers (Blanco, 1998; Baretti et al., 2000; Jha et al., 1999; Bahl, 1971). As an alternative to this approach, a few studies used nonparametric techniques such as DEA (Data Envelopment Analysis) ${ }^{1}$ to measure the productive efficiency of tax collection (Moesen and Persoon, 2002; Thirtle et al., 2000; Førsund et al., 2005; Barros, 2007). Yet, due to the deterministic nature of nonparametric models, inefficiencies due to the presence of atypical observations, measurement errors, omitted variables, and other statistical discrepancies are not taken into

1 Charnes, Cooper and Rhodes (1978).

Est. Econ., São Paulo, vol. 42, n.1, p. 43-74, jan.-mar. 2012 
account. Additionally, when the dataset is both large and diverse, this problem is aggravated, leading to substantial underestimation of efficiency scores since the frontier is given by a small number of municipalities. Therefore, to make efficiency scores credible it is necessary to use an adequate procedure to correct those scores for outliers.

Moreover, although tax revenue is observable, one cannot rely uniquely on this variable to estimate tax effort. Indeed, tax collection is affected by many factors outside the control of municipalities such as political factors, socio-economic characteristics, and idiosyncratic shocks to some specific tax bases, which are seldom well controlled for when estimating tax capacity. Hence, the use of tax efficiency measures based only on controllable outputs and inputs may distort the observed performance of a given tax jurisdiction and lead to unreliable results.

There are different ways to consider exogenous factors in a nonparametric framework. We can, for instance, introduce them directly as constraints in the linear program. The main shortcoming of this approach comes from the fact that due to the so called curse of dimensionality, for a fixed number of observations, the use of a multitude of parameters tends to overstate the efficiency of the observations. The second practice is to use a two-stage approach. In the first stage one computes DEA measures while treating all the inputs as controllable and then, in the second stage, regresses the "gross" computed efficiency scores on exogenous factors in order to get a "pure" measure of technical efficiency (McCarty and Yaisawarng, 1993; Yu, 1998; Simar and Wilson, 2005). This two step approach allows to detect the factors that determines "gross" efficiency scores and it also permits to compute the "pure" managerial"" efficiency scores from the residuals of the regression. This procedure will be adopted in this study.

The objective of this paper is to evaluate the efficiency of tax collection in Brazilian municipalities by applying a two-stage approach. Firstly, we will compute output-oriented robust DEA efficiency indexes by using bootstrap and jackknife resampling techniques ("jackstrap") to correct for outliers and possible errors in the dataset. Secondly, we will regress the computed nonparametric scores on environmental variables to account for exogenous factors that might 
affect the municipality's performance and will use the regressions residuals to compute "pure" efficiency scores. Our approach differs from previous work by specifying a "pure" robust nonparametric efficiency index and in the use of quantile regression techniques. Robust indexes are particularly important when the dataset is both large and heterogeneous, as is our case. Finally, the use of quantile regression allows the impacts of the conditioning variables to differ across the distribution of tax efficiency scores.

The paper unfolds as follows. Section 2 presents the background and Section 3 describes the methodology used to compute the outlierscorrected DEA "pure" efficiency scores. Section 4 briefly describes the data for both stages. Sections 5 and 6 discuss the results and compare the technical efficiency scores with the residual ones. Finally, Section 7 summarizes the main conclusions.

\section{Background}

The first studies dealing with government tax performance were based on country level data. Bahl (1971), in a pioneer work, investigated this issue on a tax effort framework and set up the path for subsequent studies. Those tax effort models emphasized the importance of supply factors - e.g. the magnitude of the tax base and the existence of easily taxed economic activities - to explain country tax performances (Leuthold, 1991; Piancastelli, 2001). More recently, the conventional literature on tax effort was extended into several directions. Particular attention was given to the estimation of a production function based on stochastic tax frontiers (Battese and Coelli, 1992) to assess potential tax revenues; by comparing their results with the observed tax revenues, they computed tax effort indexes and hence, country tax performances (Jha et al., 1999; Esteller-Moré, 2005). More recently, the tax effort models were extended to include demand characteristics such as corruption and accountability as determinants of tax effort and tax performance (Bird and Tarasov, 2008). Concomitantly, several studies applied these methodologies to government lower spheres (Jha et al., 1999; Bird and Tarasov, 2004). As for Brazil, Reis and Blanco (1996) and Ribeiro (1998) analyzed tax performance by means of stochastic frontier methods for the Brazilian states and municipalities. In a subsequent work, Blanco (1998) used a two stage methodology, in 
which the tax effort indexes from the first stage were regressed on several variables that could influence tax effort. Those studies concluded that transfers, by acting as a substitute to tax collection, had a negative effect on tax efficiency of the states and municipalities. Posterior analyses focused on specific regions, included capital revenues, labor market informality and municipal characteristics to explain tax inefficiencies following the line of traditional tax effort models. Vasconcelos et al. (2006) and Orair and Alencar (2010), on the other hand, estimated tax effort of states and municipalities in Brazil by using OLS regressions. Finally, a few studies computed tax efficiency scores for subnational government levels by means of nonparametric methods such as DEA (Gasparini and Melo, 2004). However, these studies, besides using a naïve version of those methods, do not try to explain the calculated tax efficiency scores.

This paper links the tax effort literature with efficiency analysis by means of a two stage approach that combines advanced nonparametric techniques and quantile regression models to compute tax efficiency indexes and identify environment variables - not controlled by tax administrators - that may affect tax efficiency (implicit tax effort) for the Brazilian municipalities. This enables us to compute "pure" efficiency indexes, which reflect only differences in tax management.

\section{Methodology}

Nonparametric methods, such as DEA have been widely used to evaluate relative performance in different areas. These techniques, based on productivity analysis (Koopmans, 1951, Farrel, 1957) do not impose a parametric structure, but require only weak assumptions concerning the production technology such as convexity, free disposal and scale restrictions. The main drawbacks of DEA is that the resulting efficiency scores are influenced by the presence of Decision Making Units (DMUs) that perform extremely well (the so called outliers), which indicate outstanding practices or may simply be the result of errors in the data. In either case, the results for the remaining DMUs are shifted downwards, the efficiency frequency distribution becomes highly asymmetric, and the overall efficiency scale becomes non-linear. Several authors have considered this effect. Wilson (1993) introduced descriptive methods to detect influential 
observations in nonparametric efficiency calculations. More recent developments of this important issue include the order- $m$ frontiers (Simar, 2003; Cazals, Florens and Simar, 2002) and the Robust Efficiency Frontier (Cherchye, Kuosmanen and Post, 2000).

Yet, these approaches are heavily dependent on manual inspection of data, which becomes virtually impossible for large data sets. To tackle this issue, we shall use a method recently proposed by Sampaio de Sousa and Stosic (2005), which combines bootstrap and jackknife resampling schemes for automatic detection of outliers. This approach is based on the concept of leverage, that is, the effect produced on the outcome of DEA efficiencies of all the other DMUs when the observed DMU is removed from the data set. Leverage measures are calculated for each DMU, and it is then used to detect outliers and to eliminate them in an automated fashion, or to just reduce their influence. The underlying idea is that outliers are expected to display leverage much above the mean leverage, and hence should be selected with lower probability than the other DMUs when resampling is performed. Below, we will describe this method.

\subsection{First Step: Naive and Robust Technical Efficiency Scores}

Suppose the existence of $K$ DMUs. The technology converts nonnegative inputs $x^{k}=\left(x_{k 1}, \ldots, x_{k N}\right) \in \mathfrak{R}_{+}^{N}$ into nonnegative outputs $y^{k}=\left(y_{k 1}, \ldots, y_{k M}\right) \in \mathfrak{R}_{+}^{M}$. The production set of the feasible inputoutput combinations, given by $T=\{(x, y)$ : $x$ can produce $y\}$, can be described by the output requirement set, $P(x)=\left\{y \in \mathfrak{R}_{+}{ }^{M} \mid(x, y) \in T\right\}$. Returns of scale, $r$, require that if $(x, y) \in T$, then $(\zeta x, \zeta y) \in$, $\forall \zeta \in S(r)$, where $r=$ "crs" stands for constant returns to scale, $r=$ "drs" for decreasing returns and $r=$ "vrs" for variable returns; $S(c r s)=R_{+}, S(d r s)=[0,1]$ and $S(v r s)=\{1\}$.

The radial efficient boundary of $T$ corresponds to the frontier transformation function, $\partial P(x)$ :

$$
\partial P(x)=\{y \mid y \in P(x), \lambda y \in P(x), \forall \lambda>1\}
$$

Here, we move to the frontier by expanding outputs while keeping inputs fixed. The output-oriented measure of efficiency for a DMU at $(x, y)$ is given by: 


$$
\lambda(x, y)=\sup \{\lambda \mid \lambda y \in P(x)\}
$$

As $T$ and $\partial P(x)$ are unknown, the efficiency measures $\lambda(x, y)$ have to be estimated. Among them, the most popular are the DEA estimators. The DEA estimator of the output section of $T$ is:

$\tilde{T}_{D E A}=\left\{(x, y) \in \mathfrak{R}_{+}^{M+N} \mid y \leq \sum_{k=1}^{K} \gamma_{k} y_{k}, x \geq \sum_{k=1}^{K} \gamma_{k} x_{k}, \sum_{k=1}^{K} \gamma_{k} x_{k} \leq 1 \gamma_{j_{k}} \geq 0, k=1, \ldots, n\right\}(3)$

Replacing T with its DEA estimator in $P(x), \partial P(x)$ gives, respectively,

$$
\begin{aligned}
& \tilde{P}(x)=\left\{y \in \mathfrak{R}_{+}^{N} \mid(x, y) \in \widetilde{T_{D E A}}\right\} \\
& \partial \tilde{P}(x)=\left\{y \in \mathfrak{R}_{+}^{N} \mid x \in \tilde{P(x)}, \lambda y \notin \tilde{P(x)}, \forall \lambda>1\right\}
\end{aligned}
$$

Accordingly, the correspondent output-oriented measure of technical efficiency is:

$$
\lambda_{D E A}^{\sim}(x, y)=\sup \{\lambda y \in \tilde{P(x)}\}=\sup \left\{\lambda \mid(x, y \lambda) \in \widetilde{T_{D E A}^{\sim}}\right\}
$$

\subsection{Leverage and the "Jackstrap" Procedure}

The leverage of a single observed DMU might be understood as the impact of the removal of the DMU from the dataset on the efficiency scores of all the other DMUs. Formally, it may be defined as the standard deviation of the post-removal efficiency measures from their pre-removal values. The straightforward possibility is to use jackknife resampling as follows. One first applies DEA using the unaltered, original dataset to obtain the set of efficiencies $\left\{\lambda_{k} \mid k=1, \ldots, K\right\}$ for each of the DMUs. Then, one by one, each DMU is successively removed from the dataset, and each time the set of efficiencies $\left\{\lambda_{k j}^{*} \mid k=1, \ldots, K ; k \neq j\right\}$ is recalculated, where $j=1, \ldots, K$ indexes the removed DMU. The leverage of the $j$-th DMU may then be defined as 


$$
\ell_{j}=\sqrt{\frac{\sum_{k=1 ; k \neq j}^{K}\left(\lambda_{k j}^{*}-\lambda_{k}\right)^{2}}{K-1}}
$$

However, this approach is extremely computationally intensive and may prove unfeasible for large datasets. More precisely, removing each of the $K$ DMUs from the data set and then performing (K-1) DEA calculations requires solving $K(K-1)$ linear programming problems, which may become prohibitively expensive for large $K$. Sampaio de Sousa and Stosic (2005) proposed a more efficient stochastic procedure, which combines bootstrap resampling with the above jackknife scheme as follows:

- Randomly select a subset of $L$ DMUs and perform the above procedure to obtain subset leverages $\tilde{\ell}_{k 1}$, where the index $k$ takes on $L$ (randomly selected) values from the set $\{1, \ldots, K\}$.

- Repeat the above step $B$ times, accumulating the subset leverage information $\tilde{\ell}_{k b}$ for all randomly selected DMUs (for $B$ large enough, each DMU should be selected roughly $n_{k} \approx B L / K$ times),

- Calculate mean leverage for each DMU as

$$
\tilde{\ell}_{k}=\frac{\sum_{b=1}^{n_{k}} \tilde{\ell}_{k b}}{n_{k}}
$$

- Compute the global mean leverage as

$$
\tilde{\ell}=\frac{\sum_{k=1}^{K} \tilde{\ell}_{k}}{K}
$$

This completes the first phase of the proposed approach. In the second phase, one can either use the leverage measures to detect and simply eliminate outliers from the dataset, or one can implement a bootstrap method to produce confidence intervals and bias information, using leverage information to reduce the probability of selecting the identified outliers in the stochastic resampling process. The point here is how leverage information can be used to identify potential outliers (and/or errors). More precisely, after ordering the 
DMUs according to their leverage values such that $\tilde{\ell}_{i} \geq \tilde{\ell}_{j}$ for $i<j$ , a choice should be made as to what threshold leverage value $\tilde{\ell}_{o}$ should be used to warn of potential influential DMUs. Here, we will use the Heaviside step function, that takes into account leverage information and the sample size $\mathrm{K}$ as follows

$$
P\left(\tilde{l}_{k}\right)=1 \text {, se } \tilde{l}_{k} \leq \tilde{l} \log K \text { e } P\left(\tilde{l}_{k}\right)=0 \text {, se } \tilde{l}_{k}>\tilde{l} \log K
$$

where $P\left(\tilde{l_{k}}\right)$ is the probability of retaining $k$-th DMU, with leverage $l_{k}$. Here, to take into account the sample size $K$, the threshold level was chosen as the product of the global leverage $l$ and the natural logarithm of $K$.

\subsection{Second Step: Residual Efficiency Scores}

Let $\lambda=\left(\lambda_{1}, \ldots, \lambda_{k}\right)^{\prime}$ be the vector of efficiency scores, $X$ a matrix of dimension $K \times p$ containing the municipality characteristics, $\beta$ a $p$ dimensional vector of unknown parameters and $u$ a $K$-dimensional vector of random errors. We can write a regression model as

$$
\ln \lambda_{k}=f\left(x_{k} ; \beta\right)+u_{k}, \quad k=1, \ldots, K
$$

Notice that the above expression may be seen as the decomposition of the gross efficiency score, $\lambda_{k}$, into two parts: the exogenous component, given by $f\left(x_{k} ; \beta\right)$ and the managerial performance, given by $u_{k}$. More precisely, this estimated residual represents the deviation from the mean managerial performance that would be observed in a given environment. Hence, the residual (or "pure" technical efficiency) for the $k$-th municipality, $E f_{K}$, is given by:

$$
E f_{k}=\exp \left(u_{k}-u_{\max }\right), \quad k=1, \ldots, K
$$

Where $u_{\max }$ is the maximum of $\left\{u_{k}\right\}$. The municipality with the highest positive $u$ will be considered efficient. Note that the scores defined by [12] are purged from exogenous factors. By construction the new efficiency measure will be between 0 and 1 . These scores will serve to rank the communes and this ranking will be confronted with the one obtained by using the nonparametric measures in the first stage. 


\section{Data}

The implementation of the methods presented above requires data on municipal tax revenues (outputs) and information on inputs to compute nonparametric efficiency scores as well as information on municipal characteristics that will be used to calculate pure scores.

For the first step, tax revenues for 2902 tax jurisdictions (municipalities) for the year 2004 were obtained from the National Treasury Secretariat (Secretaria do Tesouro Nacional, STN) and are in 2004 Brazilian Reais. We considered only tax revenues derived from taxes collected by the municipality. Other sources of revenues such as grants from State and Central governments and credit operations were excluded. The following taxes were considered: (a) Tax on Real State Property (Imposto sobre a Propriedade Predial e Territorial Urbana, IPTU), (b) Tax on Services (Imposto sobre Serviços de Qualquer Natureza, ISSQN), (c) Income Tax on Municipal Government's Payroll (Imposto de Renda Retido nas Fontes sobre o Rendimento do Trabalho, IRRF), ${ }^{2}$ (d) Tax on Property Transmission (Imposto sobre Transmissão "Inter Vivos" de Bens Móveis e de Direitos Reais sobre Imóveis, ITBI), (e) Local Police Services Fees (Taxas pelo Poder de Polícia, TPP), (f) Public Services Fees (Taxas pela Prestação de Serviços, TPS) and (g) the Improvement Contribution (Contribuição de Melhoria, CM). Those taxes have a high correlation with the economic base of the tax jurisdiction - activity, income and wealth - and are assigned to the municipality. They are controlled by the municipality, and thus constitute an appropriated measure to compute tax efficiency and tax effort.

To compute tax efficiency scores, we grouped local taxes into five products. P1 comprehends tax revenues accruing from IPTU and P2 accounts for those coming from ISSQN. Together, these taxes represent approximately $50 \%$ of total municipal tax revenues. P3 stands for the other tax revenues, corresponding to the sum of IRRF, ITBI, TPP, TPS and CM. However, municipalities' tax effort is not restricted to tax collection. It also requires a constant strain to update their tax base. For that reason, we used the production of taxpayer cadastres as an output. So, the output P4 is the quantity of buildings

2 Although the IRRF is assigned to the federal government, this tax, levied upon municipal personnel expenses, are collected by the municipality and, by constitutional determination, are administered and used by them. Hence, as the IRRF doesn't enter into the "Conta Única da União", by the vigent accounting rules, this tax is registered as municipal tax revenue. 
and unbuilt land that are registered in the cadastre of the IPTU and P5 corresponds to the number of firms and individual taxpayers registered in the cadastre of the ISSQN. As for inputs, unfortunately we do not have separate information on the costs incurred by the municipalities to collect taxes. So, we used as a proxy for inputs, administrative expenditures (II) and the number of municipal employees (I2). The former contemplate expenditures associated with the municipal bureaucracy, from which the tax bureaucracy represents a substantial part, and the latter stands for the labor inputs. As the communes do not provide a separated estimate, the number of municipal clerks overestimates the personnel engaged on the tax administration tasks. A complete list of inputs and outputs is provided in Table 4.1, together with their descriptive statistics and respective sources.

Table 4.1 - Descriptive Statistics for Inputs and Outputs - 2004

\begin{tabular}{|c|c|c|c|c|c|c|}
\hline Inputs and Outputs & Mean & Median & Std. Dev. & Min. & Max. & Source \\
\hline \multicolumn{7}{|l|}{ Inputs } \\
\hline I1. Municipal employees (\#) & 1,008 & 430 & 3,468 & 52 & 156,474 & $\mathrm{IBGE}^{\mathrm{a}}$ \\
\hline I2. Administrative expenses (R\$) & $5,148,899$ & $1,401,535$ & $18,164,636$ & 1,385 & $401,942,788$ & STN $^{b}$ \\
\hline \multicolumn{7}{|l|}{ Outputs } \\
\hline P1. IPTUC revenues $(\mathrm{R} \$)$ & $2,290,150$ & 66,688 & $40,567,891$ & 12 & $2,121,682,423$ & STN \\
\hline P2. ISSQN ${ }^{d}$ revenues $(R \$)$ & $2,934,219$ & 118,899 & $49,742,507$ & 43 & $2,592,542,002$ & STN \\
\hline P3. Other tax revenues ${ }^{\mathrm{e}}(\mathrm{R} \$)$ & $1,906,623$ & 230,265 & $22,683,412$ & 2 & $1,142,432,280$ & STN \\
\hline P4. Registries in IPTU cadastre ${ }^{\dagger}$ (\#) & 14,726 & 3,557 & 62,751 & 96 & $2,722,881$ & IBGE \\
\hline P5. Registries in ISSQN cadastre ${ }^{g}$ (\#) & 2,625 & 266 & 30,593 & 1 & $1,512,986$ & IBGE \\
\hline
\end{tabular}

(a) Brazilian Institute of Geography and Statistics (Instituto Brasileiro de Geografia e Estatística), "Perfil dos municípios brasileiros: gestão pública 2004”; (b) National Treasury Secretariat (Secretaria do Tesouro Nacional), "Finanças do Brasil - Dados Contábeis dos Municípios - 2004"; (c) Tax on real state property; (d) Tax on services; (e) The sum of revenues from the income tax on municipal government's payroll (IRRF), the tax on property transmission (ITBI), the local police services fees (TPP), the public services fees (TPS) and the improvement contribution (CM); (f) Buildings and unbuilt lands; (g) Firms and individual taxpayers.

In the second step, to estimate Equation [11], the dependent variable is the natural logaritm of the jackstrapped efficient scores for both DEA variants for the year 2004. Data for matrix X, containing municipal characteristics come from a cross section data set for two distinct samples, each one including 2734 municipalities. Both are subsamples of the original sample of 2902 communes. Differences between the original sample and these subsamples are due to (a) exclusion of outliers by the jackstrap method and (b) data availability for municipal characteristics. Table 4.2 shows descriptive statistics and sources for the independent variables used in the second stage. 


\begin{tabular}{|c|c|c|c|c|c|c|c|c|c|c|c|c|}
\hline 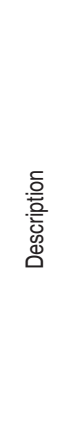 & & 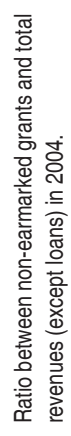 & 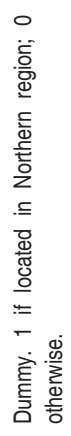 & 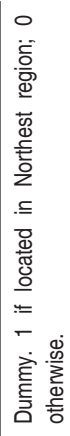 & 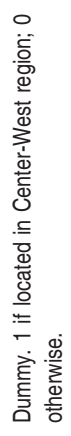 & 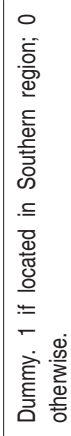 & 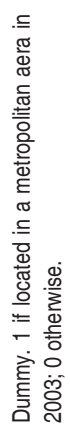 & 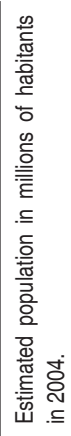 & 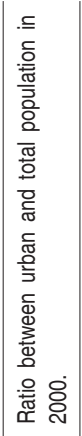 & 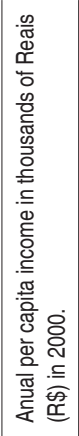 & 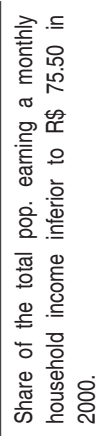 & 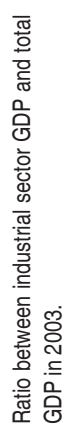 \\
\hline $\begin{array}{l}\stackrel{\Xi}{0} \\
\stackrel{\bar{z}}{\infty}\end{array}$ & & $\stackrel{\substack{z \\
\omega}}{\stackrel{m}{z}}$ & 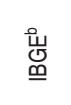 & $\begin{array}{l}\text { 岃 } \\
\underline{\underline{M}}\end{array}$ & $\begin{array}{l}\text { 峛 } \\
\underline{-1}\end{array}$ & $\begin{array}{l}\text { 峁 } \\
\underline{\underline{n}}\end{array}$ & 总 & $\begin{array}{l}\stackrel{\underline{J}}{\underline{\underline{M}}} \\
\end{array}$ & 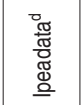 & 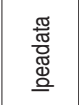 & 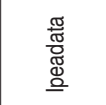 & 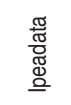 \\
\hline \multirow{5}{*}{ 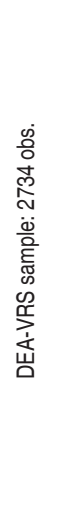 } & $\stackrel{\stackrel{x}{\pi}}{\Sigma}$ & 兽 & ه্ণ & 으 & 응 & 음 & $\underset{-}{\stackrel{\circ}{\circ}}$ & 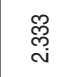 & $\underset{-}{\stackrel{8}{\circ}}$ & $\stackrel{\stackrel{\leftrightarrow}{g}}{\leftarrow}$ & $\begin{array}{l}\text { 임 } \\
\text { के }\end{array}$ & $\begin{array}{l}\mathscr{8} \\
\stackrel{8}{\circ} \\
0\end{array}$ \\
\hline & $\dot{\bar{\Sigma}}$ & $\frac{\text { m. }}{\circ}$ & 영 & 웅 & 응 & 응 & ষ্ণ & $\overline{\check{O}}$ & ঃి & ָ̃ & 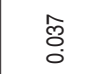 & 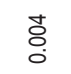 \\
\hline & के & $\frac{\bar{m}}{0}$ & $\frac{8}{\circ}$ & 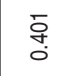 & $\stackrel{\text { ơ }}{0}$ & 䒜 & 芯 & 苂 & ָָָ & $\stackrel{\circ}{\circ}$ & 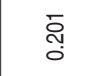 & $\frac{\infty}{\circ}$ \\
\hline & 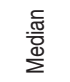 & 总 & ঃ̊ & ০̊. & @̊ & ه্. & ঃ̊ & 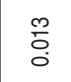 & 怘 & 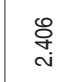 & 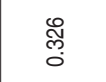 & 兽 \\
\hline & $\begin{array}{l}\stackrel{c}{\bar{\varpi}} \\
\stackrel{m}{2}\end{array}$ & 㣻 & $\begin{array}{l}\infty \\
o \\
o \\
o\end{array}$ & 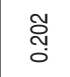 & $\begin{array}{l}\stackrel{0}{0} \\
\stackrel{0}{0}\end{array}$ & 氕 & 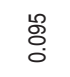 & $\stackrel{\mathscr{o}}{\circ}$ & 管 & 卓 & 怘 & $\underset{\substack{n \\
\hdashline}}{\stackrel{0}{0}}$ \\
\hline \multirow{5}{*}{ 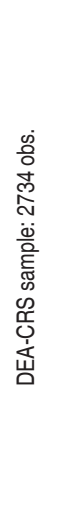 } & $\stackrel{\dot{x}}{2}$ & 总 & $\underset{-}{\stackrel{8}{\circ}}$ & $\stackrel{8}{\circ}$ & $\stackrel{\text { o }}{-}$ & $\underset{\mathrm{O}}{\stackrel{8}{-}}$ & ه্ণ & 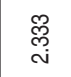 & $\underset{-}{\stackrel{8}{\circ}}$ & $\begin{array}{l}\stackrel{\leftrightarrow}{g} \\
\stackrel{+}{\leftarrow}\end{array}$ & 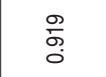 & $\begin{array}{l}\mathscr{8} \\
\stackrel{8}{\circ} \\
\stackrel{8}{0}\end{array}$ \\
\hline & $\dot{\sum}$ & $\frac{\text { m }}{\circ}$ & ㅇ. & 웅 & 영 & 웅 & ᄋ̊ & $\bar{\delta}$ & 응 & 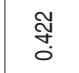 & 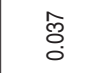 & ষ্ণ \\
\hline & 官 㐫 & $\stackrel{\bar{m}}{\circ}$ & $\frac{8}{\circ}$ & 脢 & 孞 & 突 & 怘 & $\begin{array}{l}\text { o } \\
\stackrel{0}{0} \\
0\end{array}$ & ָัָ & مُ & 灾 & $\frac{\stackrel{9}{\stackrel{9}{0}}}{0}$ \\
\hline & 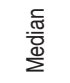 & 艿 & : & 응 & 영 & 응 & o. & $\stackrel{m}{\circ}$ & $\begin{array}{l}\stackrel{0}{\circ} \\
\stackrel{0}{0}\end{array}$ & 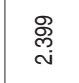 & స్ల్య & $\frac{\stackrel{R}{6}}{0}$ \\
\hline & $\begin{array}{l}\stackrel{c}{\mathbb{\varpi}} \\
\stackrel{\mathbb{m}}{2}\end{array}$ & 驾 & $\begin{array}{l}\text { o } \\
\stackrel{\delta}{0}\end{array}$ & స్ ญิ & 영 & 於 & ס̊ & 范 & $\begin{array}{l}\frac{0}{0} \\
0 \\
0\end{array}$ & 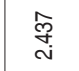 & $\begin{array}{l}0 \\
\stackrel{0}{\rho} \\
0\end{array}$ & 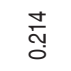 \\
\hline 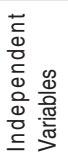 & & 胥 & $\underline{E}$ & 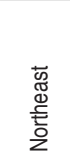 & 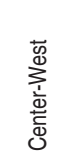 & 言 & 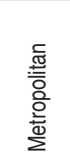 & 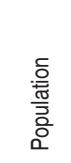 & 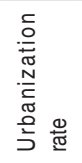 & 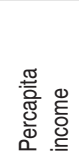 & 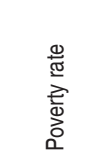 & 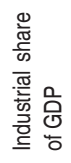 \\
\hline
\end{tabular}




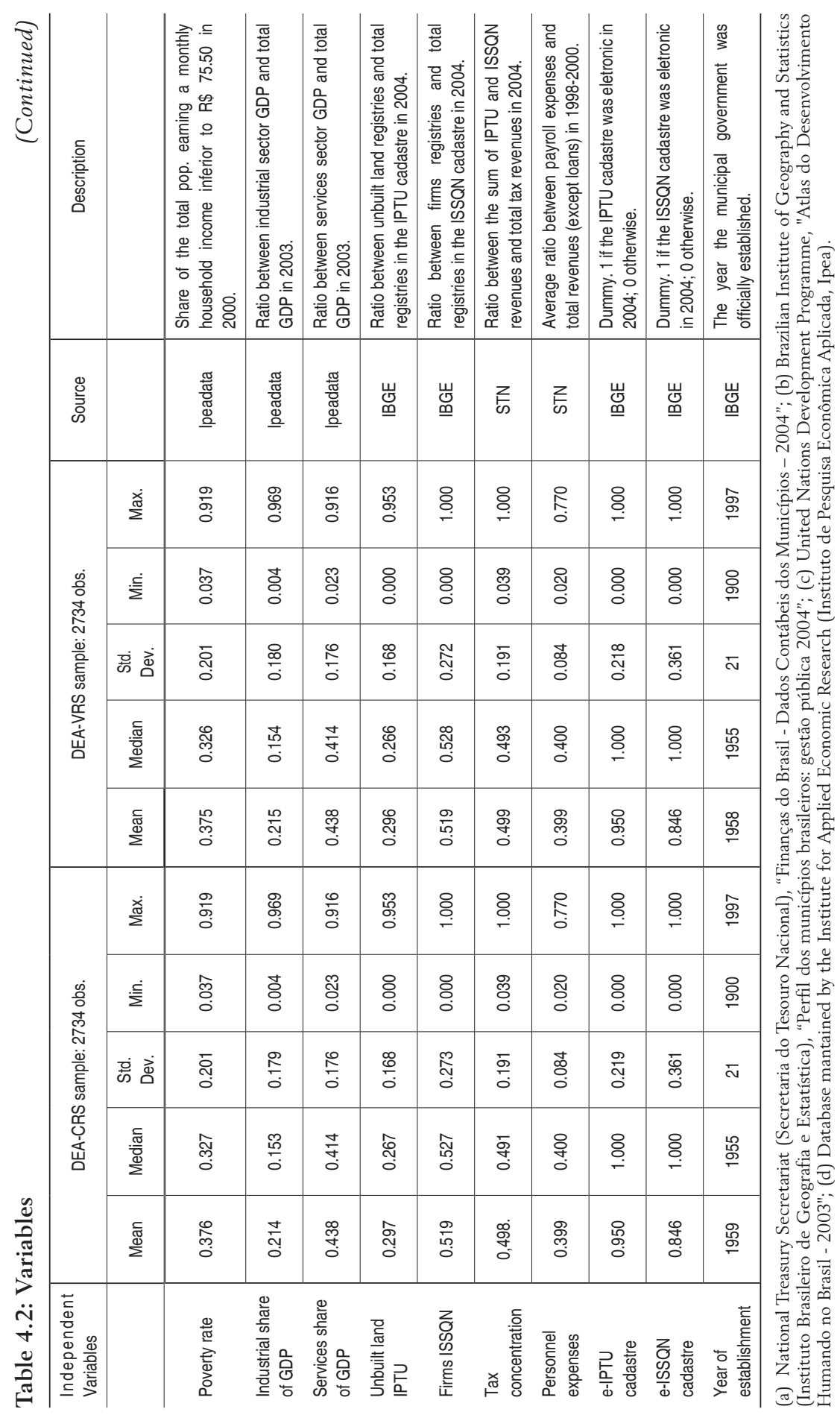




\section{5. “Jackstrapped" Results}

In this section we present the results from applying the "Jackstrap" procedure described in Section 3 to the data discussed in Section 4. We will first comment the leverage results, then we present the outlier detection process by using the Heaviside step function, and finally we discuss robust DEA efficiency calculations.

\subsection{Leverages}

Leverages were calculated for 2902 municipalities for output-oriented DEA-CRS and DEA-VRS. Table 5.1 presents leverages for the 30 most influential municipalities. Let us now briefly comment the results. Distinct and non excludable groups of influential DMUs are identified: firstly, we have municipalities for which all output-input ratios were well above the average. Examples of such cases are São Paulo, Belém, Curitiba and Belo Horizonte. In the second group, high leverages are due to a distortion in the ratio between the number of registries in the cadastre of IPTU and the number of municipal employees; this is the case of Balneário Gaivota, Iguape and Balneário Arroio do Silva. Finally, many of those super efficient cities are small towns located in touristy areas close to large and densely populated urban areas. Their valuable real state property as well as a more diversified offer of services contributes to increase their tax base; they also tend to have lower administrative expenses and hence higher ratio between tax revenues and these expenses. For instance, those rations are 3.9, 4.4 and 5.1, respectively, for Caldas Novas, Ubatuba and Praia Grande whereas the average ratio is only 0.5 .

As expected, leverage values are lower when we use the DEA-VRS model. The higher number of efficient municipalities produced by this variant contributes to mask the problem of outliers. However, as the leverage results in this model are simply scaled down with respect to the ones obtained by the DEA-CRS variant, the identification of outliers, by using the "Jackstrap" method, is similar in both models as can be seen from the ranks shown in Table 5.1. 
Table 5.1 - Leverages for Selected Municipalities

\begin{tabular}{|c|c|c|c|c|}
\hline \multirow{2}{*}{ Municipality } & \multicolumn{2}{|c|}{ DEA-CRS } & \multicolumn{2}{|c|}{ DEA-VRS } \\
\hline & Rank & Leverage & Rank & Leverage \\
\hline São Paulo - SP & 1 & 0.1986 & 1 & 0.1148 \\
\hline Belém - PA & 2 & 0.1226 & 2 & 0.1072 \\
\hline Curitiba - PR & 3 & 0.1121 & 7 & 0.0560 \\
\hline Caldas Novas - GO & 4 & 0.1107 & 4 & 0.0811 \\
\hline Iguape-SP & 5 & 0.1045 & 11 & 0.0502 \\
\hline Belo Horizonte - MG & 6 & 0.0976 & 17 & 0.0346 \\
\hline São Caetano do Sul - SP & 7 & 0.0967 & 15 & 0.0360 \\
\hline Balneário Gaivota - SC & 8 & 0.0918 & 5 & 0.0609 \\
\hline Santana do Livramento - RS & 9 & 0.0884 & 71 & 0.0137 \\
\hline Palhoça-SC & 10 & 0.0872 & 6 & 0.0564 \\
\hline Poá - SP & 11 & 0.0838 & 10 & 0.0511 \\
\hline Balneário Arroio do Silva - SC & 12 & 0.0837 & 12 & 0.0432 \\
\hline Ubatuba - SP & 13 & 0.0776 & 14 & 0.0385 \\
\hline Praia Grande - SP & 14 & 0.0765 & 13 & 0.0428 \\
\hline Jundiaí - SP & 15 & 0.0710 & 29 & 0.0255 \\
\hline Criciúma-SC & 16 & 0.0700 & 172 & 0.0041 \\
\hline Salvador - BA & 17 & 0.0699 & 16 & 0.0357 \\
\hline Rolim de Moura - RO & 18 & 0.0680 & 36 & 0.0217 \\
\hline Conselheiro Lafaiete - MG & 19 & 0.0676 & 19 & 0.0344 \\
\hline Macaé - RJ & 20 & 0.0669 & 274 & 0.0014 \\
\hline Itapema - SC & 21 & 0.0609 & 40 & 0.0201 \\
\hline Passo Fundo - RS & 22 & 0.0519 & 25 & 0.0283 \\
\hline Jaguaruna - SC & 23 & 0.0506 & 22 & 0.0317 \\
\hline São Vicente - SP & 24 & 0.0505 & 55 & 0.0166 \\
\hline Planaltina - GO & 25 & 0.0502 & 35 & 0.0219 \\
\hline Porto Alegre - RS & 26 & 0.0482 & 39 & 0.0204 \\
\hline Rio Acima - MG & 27 & 0.0476 & 38 & 0.0209 \\
\hline Vitória-ES & 28 & 0.0470 & 122 & 0.0073 \\
\hline Vila Velha - ES & 29 & 0.0465 & 67 & 0.0144 \\
\hline Nova Friburgo - RJ & 30 & 0.0461 & 294 & 0.0011 \\
\hline
\end{tabular}




\subsection{Outlier Detection}

As mentioned in Section 3, in order to determine which municipalities should be considered outliers, we will use a Heaviside rule to remove outliers (Equation [10]). We removed 66 and 52 municipalities, respectively, for DEA-CRS and the DEA-VRS variants. It should be noted that even when a city displays only local influence such e.g. Planaltina, and hence has little effect on the overall efficiency scores, our "Jackstrap" procedure identifies this anomalous case. As it performs a comparison in $B$ different random "bubbles", where it turns out that this city often demonstrates a high level of influence, it obtains a high leverage value. Hence, the "Jackstrap" procedure combined with the threshold value defined by the Heaviside function provide a reasonable and automated approximation of the number of outliers. Of course as any cutoff level, this is somewhat arbitrary but it proved to be, in our experience, a quite robust rule. ${ }^{3}$

\subsection{Efficiency Indexes}

The histograms of efficiency indices obtained through DEA-CRS calculations on the whole dataset and after removing 66 municipalities with highest leverage, are shown in Figure 5.1. It is seen that removing the high leverage DMUs generates substantial changes on the overall efficiency scores, whose distribution was originally highly asymmetric and shifted towards the lower efficiency side, as may be expected in the presence of outliers. It should be noted that the number of removed DMUs represents less than 2.5\% of the original sample.

3 For a more detailed discussion of the impact of selecting different cutoff rules in a controlled environment, see Sampaio de Sousa and Stosic (2005). 

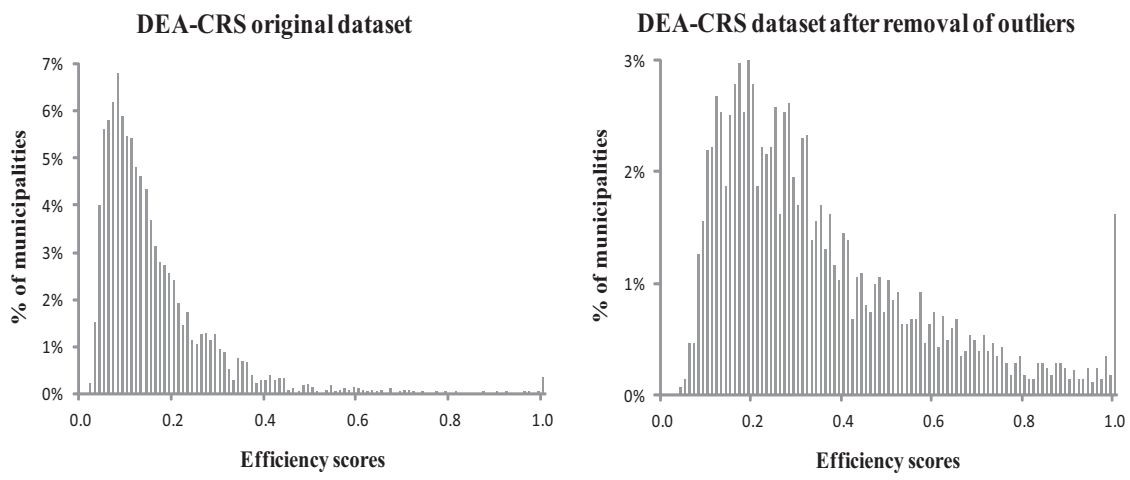

Figure 5.1 - Histograms of DEA-CRS Tax Efficiency Scores obtained by using the Original Dataset and after Removing 66 Municipalities with the Highest Leverages

Table 5.2 summarizes the results obtained according to two DEA variants. As expected, the DEA naïve frontiers are formed by a few municipalities. The uncorrected scores are quite distorted, with the majority of efficiencies being close to zero. Here, the presence of outliers not only affects the number of efficient municipalities, but also substantially influences the magnitude of the computed scores, particularly when the DEA-CRS technique is used. Indeed, between the uncorrected score and its equivalent using the Heaviside step function, the average efficiency scores doubles. Observe also that the skewness as well as the kurtosis drops substantially when the outliers are removed, indicating that the distribution of the efficiency scores thus obtained is closest to the normal distribution.

Table 5.2 - Descriptive Statistics for DEA-CRS and DEA-VRS Efficiency Scores

\begin{tabular}{l|c|c|c|c|c|c|c}
\hline \multirow{2}{*}{ Methodologies } & \multirow{2}{*}{$\begin{array}{c}\text { Included } \\
\text { observations }\end{array}$} & \multirow{2}{*}{ Efficient (\#) } & \multicolumn{5}{|c}{ Descriptive Statistics } \\
\cline { 5 - 8 } & & & Mean & Median & Std. Dev. & Skewness & Kurtosis \\
\hline DEA-CRS & $2902(0)^{\mathrm{a}}$ & 10 & 0.151 & 0.117 & 0.124 & 2.818 & 12.302 \\
\hline Uncorrected & $2836(66)$ & 30 & 0.344 & 0.281 & 0.223 & 1.133 & 0.689 \\
\hline Heaviside & & & & & & & \\
\hline DEA-VRS & $2902(0)$ & 21 & 0.188 & 0.148 & 0.149 & 2.433 & 8.314 \\
\hline Uncorrected & $2850(52)$ & 113 & 0.397 & 0.338 & 0.240 & 0.956 & 0.187 \\
\hline Heaviside & & & & & & & \\
\hline
\end{tabular}

(a) The numbers of removed outliers are between parentheses. 


\section{Residual Efficiency Scores}

To complement the nonparametric analysis carried out on Section 5, we will investigate the environmental factors affecting the efficiency scores by using OLS and quantile regression methods. The residuals of this regression measure pure technical efficiency after accounting for noncontrollable factors.

\subsection{The Econometric Model}

Since the efficiency scores are restricted to assume values within the standard unit interval $(0<\lambda<1)$, the Ordinary Least Squared (OLS) estimator of the vector of regression parameters will be inconsistent in the sense that it will not converge on probability to the true unknown parameter. However, it has been shown in the literature that the use of $\ln \lambda$ as dependent variable leads to unbiased OLS estimates if the computed scores only assume strictly positive values. Furthermore, when the dependent variable is censored, the OLS estimator of the linear regression parameters will not be consistent and such inconsistency worsens with the proportion of censored observations in the sample. ${ }^{4}$ This result implies that the problem of inconsistency will not be serious when the number of censored observation is small.

Censored observations may be appropriately tackled using the Tobit model. In this model, parameters are usually estimated by Maximum Likelihood (ML) under the assumptions of normality and homoskedasticity. It is noteworthy that the absence of normality as well as the presence of heteroskedasticity will lead to inconsistent parameter estimates.

In what follows, we shall use the linear regression model instead of the Tobit model. The reasons for that choice are as follows:

1. Contrary to the Tobit model, estimation in the linear model does not require the assumption of normality; this assumption can be quite restrictive since we have no prior information about the distribution of the data. Even if is possible to define the Tobit model using nonnormal distributions, the main shortcoming remains: distributional misspecification will render unreliable inference.

4 A proof of this result, under some regularity conditions, is given in Greene (1981).

Est. Econ., São Paulo, vol. 42, n.1, p. 43-74, jan.-mar. 2012 
2. The OLS estimator in the linear regression model is unbiased, consistent and asymptotically normal even under neglected heteroskedasticity of unknown form; the same does not hold for the ML estimator in the Tobit model.

3. It is possible to obtain an estimate for the covariance matrix of the OLS estimator of $\beta$ that is consistent under both homoskedasticity and heteroskedasticity of unknown form (see below); hence, one can perform hypothesis tests that are asymptotically valid regardless of the structure of the error variances and of the error distribution. These convenient properties do not hold in the Tobit framework.

4. The proportion of censored observations in the sample is small (around 1.8\%).

Therefore, we will investigate the exogenous factors, using OLS and quantile regression methods, as introduced by Koenker and Bassett (1978). Just as classical linear regression allows one to estimate models for conditional mean functions; quantile regression methods offer a mechanism for estimating models for the conditional median function, and also for other conditional quantile functions. This allows us to investigate the impacts of the conditioning variables on the efficiency scores across different efficiency percentiles. The basic idea is to estimate the $\tau$-th quantile of efficiency conditional on the different explanatory variables, assuming that this quantile may be expressed as a linear predictor based on these variables. We considered the following conditional quantiles: 0.10 (percentile 10\%), 0.25 (lower quartile), 0.50 (median), 0.75 (upper quartile) e 0.90 (percentile 90\%). The dependent variables are the natural logarithms of the efficiency scores for two distinct samples of 2734 Brazilian municipalities computed by using the DEA-CRS and DEA-VRS. Note that the estimated coefficients are conditional to the values obtained by the DEA scores and thus they do not take into account the uncertainty associated to those scores.

Table 6.1 presents the econometric results. Let us begin with the analysis of the impact of fiscal transfers on tax efficiency. This is a relevant issue as it seems to exist a problem of moral hazard in the design of central and state government grants to local governments. Since local conditions are unknown to higher spheres of government, municipalities can easily hide their tax potential in order to qualify for a higher share of resources from these spheres. Because its cost is 
shared by national and regional taxpayers, grants may function then as a substitute for fiscal effort, stimulating inefficiency. To test this hypothesis, we regress tax efficiency scores on grants received by the communes from higher government spheres (Grants). Our results strongly confirm those views. The negative and significant coefficients associated to the variable "grants" show that the greater the proportion of municipalities' expenditure financed by central and state grants, the lower is their tax efficiency. These results corroborate previous studies ${ }^{5}$ and reaffirm the inverse relationship between grants and tax effort and tax efficiency. Concerning the regional impact, belonging to the Northeast and Northern regions reduces the municipality's tax efficiency in the OLS model. This is hardly surprising as these regions concentrate the poorest communes, which are basically financed by grants from higher government spheres. However, quantile estimates moderate this conclusion. Indeed, this result is significant only for the municipalities situated in the median quantile. Besides, except for the Center-West, the estimated coefficients are not significant for the last quantiles $(\tau=0.75$ e $\tau=$ 0.90) signaling that for tax jurisdictions relatively efficient, location is not relevant to explain tax variations. Finally, probably due to tax spillovers, belonging to a metropolitan area increases efficiency.

Table 6.1 - Tax Efficiency determinants for Brazilian Municipalities OLS and Quantile Regression Estimates

\begin{tabular}{|c|c|c|c|c|c|c|c|c|c|c|c|c|}
\hline \multirow{3}{*}{$\begin{array}{l}\text { Independent } \\
\text { Variables }\end{array}$} & \multicolumn{6}{|c|}{ Dependent variable: natural log of DEA-CRS scores } & \multicolumn{6}{|c|}{ Dependent variable: natural log of DEA-VRS scores } \\
\hline & OLS & $\tau=0.1$ & $\tau=0.25$ & $\tau=0.5$ & $\tau=0.75$ & $\tau=0.9$ & OLS & $\tau=0.1$ & $\tau=0.25$ & $\tau=0.5$ & $\tau=0.75$ & $\tau=0.9$ \\
\hline & $\begin{array}{c}\text { coeff. } \\
\text { p-value }\end{array}$ & $\begin{array}{c}\text { coeff. } \\
\text { p-value }\end{array}$ & $\begin{array}{c}\text { coeff. } \\
\text { p-value }\end{array}$ & $\begin{array}{c}\text { coeff. } \\
\text { p-value }\end{array}$ & $\begin{array}{c}\text { coeff. } \\
\text { p-value }\end{array}$ & $\begin{array}{c}\text { coeff. } \\
\text { p-value }\end{array}$ & $\begin{array}{c}\text { coeff. } \\
\text { p-value }\end{array}$ & $\begin{array}{l}\text { coeff. } \\
\text { p-value }\end{array}$ & $\begin{array}{c}\text { coeff. } \\
\text { p-value }\end{array}$ & $\begin{array}{c}\text { coeff. } \\
\text { p-value }\end{array}$ & $\begin{array}{c}\text { coeff. } \\
\text { p-value }\end{array}$ & $\begin{array}{c}\text { coeff. } \\
\text { p-value }\end{array}$ \\
\hline \multirow[t]{2}{*}{ Constant } & 7.305 & 10.163 & 8.196 & 8.845 & 7.460 & 3.015 & 3.124 & 7.418 & 4.183 & 4.821 & 1.480 & -3.324 \\
\hline & 0.0000 & 0.0000 & 0.0000 & 0.0000 & 0.0000 & 0.0270 & 0.0034 & 0.0000 & 0.0008 & 0.0001 & 0.2033 & 0.0227 \\
\hline \multirow[t]{2}{*}{ Grants } & -1.322 & -1.436 & -1.344 & -1.228 & -1.369 & -1.228 & -0.562 & -0.912 & -0.706 & -0.651 & -0.436 & -0.296 \\
\hline & $<2 \mathrm{e}-16$ & 0.0000 & 0.0000 & 0.0000 & 0.0000 & 0.0000 & 0.0000 & 0.0000 & 0.0000 & 0.0000 & 0.0000 & 0.0172 \\
\hline \multirow[t]{2}{*}{ North } & -0.080 & -0.135 & -0.128 & -0.070 & 0.005 & 0.117 & -0.125 & -0.327 & -0.164 & -0.208 & 0.012 & 0.061 \\
\hline & 0.0894 & 0.0804 & 0.0515 & 0.2729 & 0.9669 & 0.2693 & 0.0221 & 0.0213 & 0.0008 & 0.0372 & 0.9046 & 0.3637 \\
\hline \multirow[t]{2}{*}{ Northeast } & -0.089 & -0.085 & -0.079 & -0.108 & -0.056 & -0.005 & -0.084 & -0.068 & -0.045 & -0.111 & -0.065 & 0.061 \\
\hline & 0.0064 & 0.0707 & 0.0818 & 0.0050 & 0.2306 & 0.9198 & 0.0260 & 0.2217 & 0.3209 & 0.0156 & 0.1754 & 0.4179 \\
\hline \multirow[t]{2}{*}{ Center-West } & 0.155 & 0.151 & 0.109 & 0.135 & 0.179 & 0.234 & 0.052 & 0.025 & 0.030 & 0.049 & 0.061 & 0.108 \\
\hline & 0.0000 & 0.0060 & 0.0043 & 0.0002 & 0.0000 & 0.0004 & 0.1615 & 0.5868 & 0.5058 & 0.2403 & 0.0718 & 0.0044 \\
\hline \multirow[t]{2}{*}{ South } & 0.031 & 0.142 & 0.071 & 0.063 & 0.024 & -0.012 & 0.032 & 0.057 & 0.088 & 0.043 & -0.005 & -0.040 \\
\hline & 0.1903 & 0.0000 & 0.0115 & 0.0106 & 0.3606 & 0.6970 & 0.2404 & 0.1157 & 0.0047 & 0.1230 & 0.8405 & 0.3792 \\
\hline
\end{tabular}

5 Reis and Blanco (1996); Ribeiro (1998); Blanco (1998).

Est. Econ., São Paulo, vol. 42, n.1, p. 43-74, jan.-mar. 2012 
(Continued)

\begin{tabular}{|c|c|c|c|c|c|c|c|c|c|c|c|c|}
\hline \multirow{3}{*}{$\begin{array}{l}\text { Independent } \\
\text { Variables }\end{array}$} & \multicolumn{6}{|c|}{ Dependent variable: natural log of DEA-CRS scores } & \multicolumn{6}{|c|}{ Dependent variable: natural log of DEA-VRS scores } \\
\hline & OLS & $\tau=0.1$ & $\tau=0.25$ & $\tau=0.5$ & $\tau=0.75$ & $\tau=0.9$ & OLS & $\tau=0.1$ & $\tau=0.25$ & $\tau=0.5$ & $\tau=0.75$ & $\tau=0.9$ \\
\hline & $\begin{array}{c}\text { coeff. } \\
\text { p-value }\end{array}$ & $\begin{array}{l}\text { coeff. } \\
\text { p-value }\end{array}$ & $\begin{array}{l}\text { coeff. } \\
\text { p-value }\end{array}$ & $\begin{array}{c}\text { coeff. } \\
\text { p-value }\end{array}$ & $\begin{array}{c}\text { coeff. } \\
\text { p-value }\end{array}$ & $\begin{array}{c}\text { coeff. } \\
\text { p-value }\end{array}$ & $\begin{array}{c}\text { coeff. } \\
\text { p-value }\end{array}$ & $\begin{array}{l}\text { coeff. } \\
\text { p-value }\end{array}$ & $\begin{array}{l}\text { coeff. } \\
\text { p-value }\end{array}$ & $\begin{array}{c}\text { coeff. } \\
\text { p-value }\end{array}$ & $\begin{array}{l}\text { coeff. } \\
\text { p-value }\end{array}$ & $\begin{array}{c}\text { coeff. } \\
\text { p-value }\end{array}$ \\
\hline \multirow[t]{2}{*}{ Metropolitan } & 0.112 & 0.117 & 0.102 & 0.107 & 0.105 & 0.051 & 0.099 & 0.093 & 0.076 & 0.083 & 0.096 & 0.034 \\
\hline & 0.0003 & 0.0089 & 0.0086 & 0.0003 & 0.0184 & 0.2730 & 0.0048 & 0.0067 & 0.0428 & 0.0119 & 0.0013 & 0.4364 \\
\hline \multirow[t]{2}{*}{ Population } & 0.269 & 0.265 & 0.218 & 0.378 & 0.223 & 0.164 & 0.713 & 0.737 & 0.689 & 0.919 & 0.678 & 0.470 \\
\hline & 0.0087 & 0.0060 & 0.1083 & 0.0000 & 0.0813 & 0.2912 & 0.0000 & 0.0000 & 0.0004 & 0.0000 & 0.0000 & 0.0042 \\
\hline \multirow[t]{2}{*}{ Urbanization rate } & 0.579 & 0.726 & 0.689 & 0.582 & 0.491 & 0.528 & 0.413 & 0.690 & 0.655 & 0.377 & 0.252 & 0.033 \\
\hline & $<2 \mathrm{e}-16$ & 0.0000 & 0.0000 & 0.0000 & 0.0000 & 0.0000 & 0.0000 & 0.0000 & 0.0000 & 0.0000 & 0.0001 & 0.7293 \\
\hline \multirow[t]{2}{*}{ Per capita income } & 0.118 & 0.163 & 0.145 & 0.113 & 0.084 & 0.039 & 0.044 & 0.082 & 0.064 & 0.021 & 0.004 & -0.014 \\
\hline & 0.0000 & 0.0000 & 0.0000 & 0.0000 & 0.0002 & 0.0364 & 0.0258 & 0.0002 & 0.0015 & 0.1369 & 0.8080 & 0.4844 \\
\hline \multirow[t]{2}{*}{ Poverty rate } & -0.464 & -0.386 & -0.503 & -0.542 & -0.531 & -0.725 & -0.820 & -0.796 & -0.872 & -0.963 & -1.040 & -1.052 \\
\hline & 0.0000 & 0.0170 & 0.0001 & 0.0000 & 0.0002 & 0.0000 & 0.0000 & 0.0000 & 0.0000 & 0.0000 & 0.0000 & 0.0000 \\
\hline \multirow[t]{2}{*}{$\begin{array}{l}\text { Industrial share } \\
\text { of GDP }\end{array}$} & 0.283 & 0.301 & 0.199 & 0.215 & 0.258 & 0.383 & 0.076 & 0.028 & 0.062 & 0.004 & 0.113 & 0.205 \\
\hline & 0.0000 & 0.0000 & 0.0080 & 0.0007 & 0.0005 & 0.0001 & 0.2638 & 0.7892 & 0.4014 & 0.9530 & 0.0882 & 0.0595 \\
\hline \multirow{2}{*}{$\begin{array}{l}\text { Services share } \\
\text { of GDP }\end{array}$} & 0.002 & 0.121 & 0.067 & 0.066 & 0.101 & 0.115 & 0.207 & 0.076 & 0.217 & 0.173 & 0.419 & 0.505 \\
\hline & 0.9811 & 0.2121 & 0.3941 & 0.3726 & 0.2190 & 0.2490 & 0.0059 & 0.4623 & 0.0141 & 0.0397 & 0.0000 & 0.0000 \\
\hline \multirow[t]{2}{*}{ Unbuilt land IPTU } & 0.761 & 0.741 & 0.669 & 0.820 & 0.911 & 0.777 & 0.875 & 0.876 & 0.808 & 0.957 & 0.959 & 0.753 \\
\hline & $<2 \mathrm{e}-16$ & 0.0000 & 0.0000 & 0.0000 & 0.0000 & 0.0000 & $<2 \mathrm{e}-16$ & 0.0000 & 0.0000 & 0.0000 & 0.0000 & 0.0000 \\
\hline \multirow[t]{2}{*}{ Firms ISSQN } & 0.061 & 0.058 & 0.077 & 0.065 & 0.041 & 0.026 & -0.015 & 0.017 & 0.040 & 0.026 & -0.009 & -0.106 \\
\hline & 0.0382 & 0.1950 & 0.0478 & 0.0596 & 0.3011 & 0.5959 & 0.6675 & 0.7279 & 0.3343 & 0.5182 & 0.8169 & 0.0521 \\
\hline \multirow[t]{2}{*}{ Tax concentration } & -0.032 & -0.206 & -0.050 & -0.007 & 0.033 & 0.097 & 0.036 & -0.029 & -0.044 & 0.102 & 0.049 & 0.171 \\
\hline & 0.5289 & 0.0069 & 0.4451 & 0.9027 & 0.6136 & 0.2192 & 0.5425 & 0.7382 & 0.5232 & 0.1405 & 0.4670 & 0.0540 \\
\hline \multirow[t]{2}{*}{$\begin{array}{l}\text { Personnel } \\
\text { expenses }\end{array}$} & -0.410 & -0.562 & -0.522 & -0.421 & -0.329 & -0.256 & -0.710 & -0.685 & -0.662 & -0.565 & -0.622 & -0.501 \\
\hline & 0.0000 & 0.0000 & 0.0000 & 0.0002 & 0.0123 & 0.1013 & 0.0000 & 0.0000 & 0.0000 & 0.0000 & 0.0000 & 0.0009 \\
\hline \multirow[t]{2}{*}{ e-IPTU cadastre } & 0.143 & 0.217 & 0.201 & 0.131 & 0.076 & 0.136 & 0.078 & 0.173 & 0.175 & 0.015 & 0.005 & 0.062 \\
\hline & 0.0003 & 0.0000 & 0.0057 & 0.0229 & 0.2355 & 0.0086 & 0.0889 & 0.0003 & 0.0028 & 0.7825 & 0.9038 & 0.5351 \\
\hline \multirow[t]{2}{*}{ e-ISSQN cadastre } & 0.105 & 0.050 & 0.114 & 0.108 & 0.144 & 0.103 & 0.078 & 0.045 & 0.083 & 0.095 & 0.098 & 0.100 \\
\hline & 0.0000 & 0.1662 & 0.0001 & 0.0000 & 0.0000 & 0.0114 & 0.0062 & 0.4003 & 0.0157 & 0.0077 & 0.0180 & 0.1460 \\
\hline \multirow[t]{3}{*}{$\begin{array}{l}\text { Year of } \\
\text { establishment }\end{array}$} & -0.004 & -0.006 & -0.005 & -0.005 & -0.004 & -0.002 & -0.002 & -0.005 & -0.003 & -0.003 & -0.001 & 0.001 \\
\hline & $<2 \mathrm{e}-16$ & 0.0000 & 0.0000 & 0.0000 & 0.0000 & 0.0041 & 0.0001 & 0.0000 & 0.0000 & 0.0000 & 0.0539 & 0.0467 \\
\hline & \multicolumn{6}{|c|}{$\begin{array}{l}\text { Included observations: } 2734 \\
\text { Adjusted R2: } 0.6059 \\
\text { Residual Std. Error: } 0.409 \\
\text { F-statistic: } 222.3 \\
\text { p-value: }<2.2 \mathrm{e}-16\end{array}$} & \multicolumn{6}{|c|}{$\begin{array}{l}\text { Included observations: } 2734 \\
\text { Adjusted R2: } 0.4234 \\
\text { Residual Std. Error: } 0.478 \\
\text { F-statistic: } 104.9 \\
\text { p-value: }<2.2 \mathrm{e}-16\end{array}$} \\
\hline
\end{tabular}

Scale variables - Urbanization rate and Population - have a positive and significant effect upon efficiency. Concerning population, the positive effect is well pronounced for both DEA variants. Hence, corroborating previous studies [Thirtle et al., 2000; Forsund et al., 
2005], we found that the size of the tax jurisdiction is one of the most important determinant of tax collection efficiency. As for urbanization, the positive and significant coefficients attached to this variable probably reflect the concentration of dwellings and economic activity on urban areas as well as the economies of scale on fiscal administration brought about by the economies of agglomeration that characterizes high density areas.

Among tax capacity factors - Industrial share of GDP and Service share of GDP, Per capita income and Poverty rate - per capita income and poverty rate are the most relevant. The former positively influences efficiency, but its effect decreases across quantiles. Poverty rates - measured by the share of the total population earning a monthly household income inferior to $R \$ 75.50$ - are supposed to capture tax base reductions caused by irregular property, tax reduction and exemptions and informality. Negative and significant coefficients support this view for both DEA variants. The Industrial share of GDP is significant only when we use the DEA-CRS variant. As the service tax is an important source of tax collection for municipalities, we would expect the related variable (Service share of GDP) to influence positively the efficiency scores. Yet, while having the correct sign, the coefficients associated to this variable are significant only for the DEA-VRS model; and even here, the coefficient for the lowest quantile is not significant. This result may be explained by the fact that, in Brazil, the service sector shows a high degree of informality that leads to fiscal evasion.

Together, scale and capacity factors tend to imply that the price paid by the smallest and poorest tax jurisdictions is reduced efficiency of tax collection. For these units taxation efficiency can be improved mainly by increasing the size of tax jurisdictions and by enlarging their tax base.

Concerning the characteristics of taxpayer payer cadastres for IPTU and ISSQN, two points should be considered. Firstly, as the IPTU rates are higher for unbuilt land, we expect that municipalities with a higher proportion of those lands collect more IPTU revenues, leading to higher efficiency scores for these communes. The estimated coefficients for the variable Unbuilt Land IPTU, positive and strongly significant, confirm our hypothesis. Secondly, for taxes on services (ISSQN), one might argue that is easier to audit firms than 
individual taxpayers. To test this hypothesis, we regressed the efficiency scores on the proportion of firms in the total registries in the cadastre of the ISSQN (Firms ISSQN). Our findings weakly confirm this assumption and only for the lower quantiles of the DEA-CRS variant.

Advocates of tax diversification by local governments have been found in the specialized literature. They argue that such a diversification not only would reduce the reliance on property taxes to finance local expenditures, but should also reduce the deadweight loss of the tax system, for a given revenue, by broadening the tax base and cutting rates. This, together with fiscal illusion that leads to the underestimation of the tax price, should diminish taxpayer resistance to tax increases that would lead to higher tax collection (Becker and Mulligan, 1998; Buchanan and Wagner, 1977). To consider this hypothesis we used the share of property and services taxes on total tax revenues (Tax Concentration). We expect that the greater this ratio, the lower the efficiency. The estimated coefficients, although negative, are not significant. Hence we do not find any evidence that diversifying tax base boosts revenue and tax efficiency.

Finally, the rigidity of personnel expenses, measured by the percentage of total revenues destined to pay salaries and wages taxes over the period 1998/2000, has a negative impact on tax efficiency. This result is quite robust across quantiles and methodologies. It points out that having a substantial share of revenues earmarked with personnel expenses jeopardize the flexibility required to promote administrative reforms that include cutting costs and reallocating resources into more productivity activities in terms of tax collecting. This rigidity effect is more harmful to inefficient communes located in the lowest quantile.

Let us now investigate the managerial capability of tax jurisdictions. Firstly, we include two dummy variables to capture the modernization of tax administration: the existence of electronic cadastres of taxpayers for the tax on real state property (e-IPTU cadastre) and for the tax on services (e-ISSQN cadastre) taxpayers. Here the CRS and VRS model diverge. When we use the DEA-CRS variant, coefficients for the dummy $e$-IPTU cadastre are significant except for the municipalities on quantile $\tau=0.75$; thus, having IPTU electronic taxpayer cadastres improve the efficiency of tax collection. 
However, with the DEA-VRS model, the coefficients are significant only for the lowest quantiles signaling that once the communes reach a certain level of efficiency in collecting taxes, having electronic cadastre is no longer relevant to explain efficiency. As for the dummy $e$-ISSQN cadastre, coefficients are positive and significant; nevertheless, for the VRS model, this variable is not significant for the extreme quantiles.

Secondly, the recent proliferation of small municipalities in Brazil, which lack not only a sound tax base, but also experience and managerial capability to collect taxes, may lead to reduced tax efficiency. We expect that established municipalities have a better knowledge of its tax base and a more structured tax collecting system. To test for that, we used the year when the municipal government was officially established (Year of establishment) as a proxy for expertise on administrative matters, including tax administration. The negative and significant coefficients for all quantiles obtained by both DEA methods, shows clearly that the newer the commune, the less efficient in terms of collecting tax revenues, even when we control for other factors such as size and capacity tax factors.

\section{2. "Pure” Efficiency Scores}

Using Expression [12] we computed the residual efficiency scores for the Brazilian municipalities by using the DEA-CRS and DEA-VRS variants. Table 6.2 presents technical and residual tax efficiency indexes for the ten most efficient and least efficient municipalities. For lack of space, we will show results only for the DEA-CRS method. Firstly, when we take into account noncontrolable factors, tax jurisdictions situated at the top of the distribution reduce substantially their efficiency scores. This is the case for many touristy cities and summer resorts such as Arroio do Sal and Guarapari. Their high tax revenues are not solely due to an efficient tax administration; they are rather explained by the fact that those communes concentrate a rich population that consumes high priced services and owns valuable property thus making IPTU and ISSQN much easier to collect. An obvious case is Guarapari, which is efficient when the jackstrapped method is used and whose "pure" efficiency score is only 0.2357. As for Águas de Lindóia and Águas de Santa Bárbara, they are small water springs resorts that collect a substan- 
tial amount of ISSQN, related to hotel industry and other tourism activities. These quite particular circumstances do not recommend such municipalities as role models for tax effort, as the non-adjusted efficiency indexes would suggest. Their particular situation cannot be replicated for the typical tax jurisdiction and thus they do not really represent a feasible best practice.

Table 6.2 - DEA-CRS Tax Efficiency Scores for Selected Municipalities - 2004.

\begin{tabular}{|c|c|c|c|c|c|c|}
\hline Municipality & $\begin{array}{l}\text { Population }^{a} \\
\text { (\#) }\end{array}$ & $\begin{array}{c}\text { Tax revenue } \\
\quad\left(10^{3} \mathrm{R} \$\right)\end{array}$ & $\begin{array}{l}\text { Technical } \\
\text { efficiency } \\
\text { score }\left(\lambda_{k}\right)\end{array}$ & Rank & $\begin{array}{l}\text { Residual } \\
\text { efficiency } \\
\text { score }\left(E f_{k}\right)\end{array}$ & Rank \\
\hline \multicolumn{7}{|l|}{ Most efficient } \\
\hline Bauru - SP & 344,258 & 52,983 & 1.0000 & 1 & 0.2105 & 1416 \\
\hline Piracicaba - SP & 355,039 & 78,998 & 1.0000 & 1 & 0.2330 & 1134 \\
\hline Guarapari - ES & 102,089 & 14,247 & 1.0000 & 1 & 0.2357 & 1103 \\
\hline Águas de Lindóia - SP & 18,289 & 6,914 & 1.0000 & 1 & 0.2645 & 791 \\
\hline Franca - SP & 315,770 & 40,710 & 1.0000 & 1 & 0.2678 & 763 \\
\hline Arroio do Sal - RS & 6,423 & 2,467 & 1.0000 & 1 & 0.2830 & 655 \\
\hline Arujá - SP & 70,248 & 14,742 & 1.0000 & 1 & 0.3051 & 500 \\
\hline Águas de Santa Bárbara - SP & 5,907 & 2,740 & 1.0000 & 1 & 0.3119 & 459 \\
\hline Itu - SP & 149,758 & 26,496 & 1.0000 & 1 & 0.3162 & 438 \\
\hline Rio Grande - RS & 193,789 & 30,365 & 1.0000 & 1 & 0.3213 & 410 \\
\hline \multicolumn{7}{|l|}{ Least efficient } \\
\hline Ponto dos Volantes - MG & 11,349 & 157 & 0.1556 & 2259 & 0.2227 & 459 \\
\hline Ibirapuã - BA & 6,483 & 374 & 0.1788 & 2073 & 0.2603 & 253 \\
\hline Caatiba - BA & 18,484 & 390 & 0.1911 & 1972 & 0.2984 & 140 \\
\hline Cacimbinhas - AL & 8,600 & 206 & 0.1853 & 2017 & 0.2820 & 182 \\
\hline Plácido de Castro - AC & 15,931 & 77 & 0.1449 & 2338 & 0.2245 & 448 \\
\hline Piranhas - AL & 22,854 & 465 & 0.1774 & 2085 & 0.2786 & 193 \\
\hline Carnaubeira da Penha - PE & 10,007 & 244 & 0.0919 & 2684 & 0.1991 & 683 \\
\hline Granjeiro - CE & 5,578 & 138 & 0.1639 & 2177 & 0.3123 & 116 \\
\hline Olho D’Água do Piauí - PI & 2,113 & 49 & 0.1372 & 2386 & 0.2457 & 324 \\
\hline Tarrafas - CE & 8,751 & 205 & 0.1437 & 2345 & 0.2746 & 204 \\
\hline
\end{tabular}

Sources: (a) Brazilian Institute of Geography and Statistics (Instituto Brasileiro de Geografia e Estatística, IBGE), "Perfil dos municípios brasileiros: gestão pública 2004"; (b) National Treasury Secretariat (Secretaria do Tesouro Nacional, STN), "Finanças do Brasil Dados Contábeis dos Municípios - 2004". 
For the most inefficient tax jurisdictions, "pure" efficiency indexes are superior to the non-adjusted ones. Indeed, the worse the commune-specific conditions the greater the rise in the residual efficiency score. The typical municipality situated at the bottom of the efficiency distribution is small, poor, with a very limited tax base. Their adverse environment makes them look much more inefficient than they really are. In that sense, residual scores present a more complete picture of the municipality's tax effort because the magnitude of the non-adjusted indexes reflects factors other than managerial efficiency. Hence, when we take into account environmental factors, there is a convergence between the scores across communes.

Table 6.3 shows the descriptive statistics for residual efficiency scores as well as the rank correlations between those scores and the ones computed by the jackstrapped method. Firstly, to track the mobility of tax jurisdictions across different definitions of efficiency, we computed the rank correlations between DEA jackstrapped scores and residual efficiency scores. The rank correlations are 0.60 and 0.75 , respectively, for the CRS and VRS variants. Secondly, for most communes, "pure" scores are lower than the "gross" ones. For instance, under the DEA-CRS and DEA-VRS variants, only 34\% and $2 \%$, respectively, of the municipalities have a "gross" efficiency score inferior to the residual one. The fact that this proportion is much lower - for all population groups - when the DEA-VRS was used is consistent with the fact that this variant envelops the DEACRS model.

Hence, in both DEA variants, the jackstrapped efficiency scores overestimate the "pure" efficiency scores. Such a result could be explained by the fact a significant part of the "gross" jackstrapped efficiency were due to environmental factor rather than a better management of tax revenues. 
Table 6.3 - Descriptive Statistics for DEA-CRS and DEA-VRS Residual Tax Efficiency Scores, Classified by Population Groups - 2004.

\begin{tabular}{|c|c|c|c|c|c|c|c|c|}
\hline \multirow{2}{*}{$\begin{array}{l}\text { Methodologies and } \\
\text { Population Groups }\end{array}$} & \multirow{2}{*}{$\begin{array}{c}\text { Obs. } \\
(\#)\end{array}$} & \multirow{2}{*}{$\begin{array}{c}\text { Rank } \\
\text { Correlation } \lambda_{k} \\
\text { and } E f_{k}\end{array}$} & \multirow{2}{*}{$\begin{array}{l}\text { Obs. for } \\
\text { which } \lambda_{k} \\
{ } E_{k}(\%)\end{array}$} & \multicolumn{5}{|c|}{$E f_{k}$ Descriptive Statistics } \\
\hline & & & & Mean & Median & $\begin{array}{l}\text { Std. } \\
\text { Dev. }\end{array}$ & Skewness & Kurtosis \\
\hline DEA-CRS & 2734 & 0.605 & $66 \%$ & 0.235 & 0.215 & 0.107 & 2.198 & 9.159 \\
\hline 0 to 49,999 & 2343 & 0.611 & $64 \%$ & 0.236 & 0.215 & 0.105 & 2.124 & 8.790 \\
\hline 50,000 to 299,999 & 352 & 0.616 & $82 \%$ & 0.234 & 0.207 & 0.117 & 2.525 & 10.599 \\
\hline$>300,000$ & 39 & 0.535 & $87 \%$ & 0.235 & 0.218 & 0.101 & 2.624 & 10.690 \\
\hline DEA-VRS & 2734 & 0.750 & $98 \%$ & 0.173 & 0.152 & 0.096 & 2.512 & 10.776 \\
\hline 0 to 49,999 & 2334 & 0.748 & $97 \%$ & 0.173 & 0.152 & 0.096 & 2.580 & 11.526 \\
\hline 50,000 to 299,999 & 356 & 0.793 & $100 \%$ & 0.170 & 0.147 & 0.096 & 2.141 & 6.367 \\
\hline$>300,000$ & 44 & 0.704 & $100 \%$ & 0.187 & 0.159 & 0.083 & 1.841 & 4.208 \\
\hline
\end{tabular}

When we disaggregate our results by size of the tax jurisdiction, we have a quite interesting result. Managerial tax efficiency, here measured by residual ("pure") efficiency indexes, does not seems to differ significantly across different classes of population. Indeed the mean score variations are low among municipalities of different sizes. This result is only apparently surprising. It means that efficiency heterogeneity in terms of tax collection observed among Brazilian communes, particularly among small ones, is mainly caused by their specific environmental conditions, rather than by differences in their tax administration.

Our findings suggest that to improve municipal tax efficiency we have to adopt different strategies according to the particular conditions faced by the communes. Those with a substantial tax capacity and better socioeconomic conditions might improve efficiency by better management of controllable inputs by adopting programs that boost tax collection and reduce evasion. However, communes lacking both, tax capacity and good economic conditions, face a more difficult challenge, as the tax inefficiencies are due to external factors, outside their control. In such cases, improving tax administration should be part of a more coordinated strategy aiming to improve local development that would permit to expand and/or create their tax base. 
Notice also that the positive kurtosis for all measures of tax efficiency indicate that their efficiency distributions have fat tails relative to the normal distribution. This phenomenon is so intense for the small cities that several of them present residual efficiency scores higher than the high scores of the big cities, indicating once again that their adverse environment and socioeconomic conditions accounts for most of their overall inefficiency.

Lastly, to summarize our results, Table 6.4 presents the computed aggregate tax efficiency scores for both one-stage and two-stage approaches, measured as a weighted mean of individual scores. The weights are given by the tax share of the $k$-th municipality on total tax revenue.

Table 6.4 - Aggregate Tax Efficiency Scores for Brazilian Municipalities 2004.

\begin{tabular}{lcc}
\hline \multirow{2}{*}{ Methodologies } & \multicolumn{2}{c}{ Aggregate Tax Efficiency Scores } \\
\cline { 2 - 3 } & Technical Efficiency $\left(\lambda_{k}\right)$ & Residual Efficiency $\left(E f_{k}\right)$ \\
\hline DEA-CRS & 0.684 & 0.231 \\
DEA-VRS & 0.736 & 0.164 \\
\hline
\end{tabular}

As we see, the overall tax performance of Brazilian municipalities has been quite disappointing. The low efficiency indexes here - the "gross" as well as the residual ones - show clearly that there is a wide space for increasing municipal tax effort. This conclusion is valid for small and larger cities as well as rich and poor ones. This result seems to imply that the Brazilian municipal tax jurisdiction lack appropriate incentives to adopt efficient tax systems by better exploring their tax base (when they have one), rationalizing their tax structure, and by reducing tax avoidance and evasion.

\section{Conclusion}

In this paper we first estimated the DEA-CRS and DEA-VRS technical tax efficiency scores for 2902 Brazilian municipalities by applying a method that combines bootstrap and jackknife resampling to eliminate the effect of outliers. Since tax efforts are affected by municipalities' characteristics, which were not taken into account 
in our DEA calculations, we included those factors in the analysis. To that end, we used econometric methods (including quantile regression) to investigate how the excluded variables influenced the computed "gross" efficiency scores. The econometric results proved to be quite robust to the nonparametric efficiency variants used as dependent variable.

Corroborating previous results, gross tax efficiency results show a clear relationship between the municipality's size and urbanization and its efficiency scores. Scale variables - urbanization rate and population - have a positive and significant effect upon efficiency. Indeed, under both DEA variants, smaller cities tend to be less efficient than larger ones hence indicating that size of the tax jurisdiction is a relevant determinant of tax efficiency. Tax capacity factors also proved to be a key determinant of tax efficiency. Together, scale and capacity factors tend to imply that the price to pay for smaller tax jurisdictions is reduced productivity of tax collection. Hence, technical productivity of taxation could be improved mainly by small units becoming larger.

Our findings also suggest the existence of moral hazard problem in relationship between local tax jurisdictions and the central/state governments. Fiscal transfers granted to municipalities seem to act as a substitute for tax effort so that national taxpayers can finance local expenses. This point is particularly relevant for Brazil, where the design of fiscal transfers is totally disconnected from the municipalities' performance regarding tax collection. Hence, if one wants to boost tax efficiency, it is imperative to change the rules for conceding these grants.

Moreover, the efficiency heterogeneity observed among tax jurisdictions are mainly caused by exogenous factors rather than by differences in their tax administration. The relatively low indexes, both at the individual and aggregated levels, show clearly that there is a wide space for increasing municipal tax effort in Brazil. Such a result seems to imply that Brazilian communes lack not only appropriate incentive to increase tax efforts, but also a sound tax base. 


\section{References}

Bahl, R. W. (1971). “A Regression Approach to Tax Effort and Tax Ratio Analysis”. IMF Staff Papers, n. 18 , p. 570-607.

Battese, G. (1992). "Frontier production functions and technical efficiency: a survey of empirical applications in agricultural economics". Agricultural Economics, v.7, p. 185-208.

Baretti, C., Huber, B., and Lichtblau, K. (2000). "A tax on tax revenue: the incentive effects of equalizing transfers: Evidence from Germany”. Working Paper 333, CESifo, Munich.

Barros, C. P. (2007). "Technical and allocative efficiency of tax offices: a case study". Journal of Public Sector Performance Management, 1, pp. 41-60.

Becker, Gary S. and B. C. Mulligan (1998). "Deadweight Costs and the Size of Government". Cambridge. NBER Working Paper Series. Working Paper 6789. November.

Bird R. M., Tarasov A. V. (2004). "Closing the gap: fiscal imbalances and intergovernmental transfers in developed federations". Environment and Planning C: Government and Policy, v. 22(1) 77 - 102.

Blanco, F. A. (1998). "Disparidades Interregionais, Capacidade de Obtenção de Recursos Tributários, Esforço Fiscal e Gasto Público no Federalismo Brasileiro". XX Prêmio BNDES de Dissertação de Mestrado, Rio de Janeiro: BNDES.

Boadway, R, I. Horiba and R.Jha (1999). "The provision of public services by government funded decentralized agencies”. Public Choice, v. 100, 157-184.

Buchanan, J., and Wagner, R. E. (1977). "Democracy in Deficit: The Political Legacy of Lord Keynes". New York: Academic Press.

Cazals, C., J.P. Florens and Simar, L. (2002). "Nonparametric Frontier Estimation: A Robust Approach". Journal of Econometrics, v. 106, 1-25.

Charnes, A., W. W. Cooper and E. Rhodes (1978). "Measuring Efficiency of Decision Making Units". European Journal of Operational Research, 1, 429-44.

Cherchye, L., T. Kuosmanen and G. T. Post (2000). "New Tools for Dealing with Errors in Variables in DEA". CES Discussion Paper 0006.

Deprins, D., L. Simar and H. Tulkens. (1984). "Measuring Labor Efficiency in Post Offices.” In: M.

Färe, R., S. Grosskopf and C. K. Lovell (1985). “The Measurement of Efficiency of Production”. Boston: Kluwer-Nijhoff Publishing.

Esteller-Moré, A (2005). "Is There a Connection Between the Tax Administration and the Political Power?”. International Tax and Public Finance, pp. 639-663.

Farrell, M. J. (1957). "The Measurement of Productive Efficiency", Journal of the Royal Statistical Society, A CXX, Part 3.

Førsund, F.R., S. Kittelsen and F. Lindseth (2005). "Efficiency and Productivity of Norwegian Tax Offices". Memorandum 29/2005, University of Oslo, Department of Economics.

Greene, W.H. (1981). "On the asymptotic bias of the ordinary least squares estimator of the Tobit model". Econometrica, v. 49, 505-513.

Gasparini, C. E., Melo, C. S. L. de (2004). “Equidade e Eficiência Municipal: uma Avaliação do Fundo de Participação dos Municípios - FPM”. VIII Prêmio Tesouro Nacional. Brasília: ESAF.

Instituto Brasileiro de Geografia e Estatística - IBGE (2005). "Perfil dos municípios brasileiros: gestão pública 2004". Rio de Janeiro: IBGE.

Jha, R., M. S. Mohanty S. Chatterjee and P. Chitkara (1999). "Tax effciency in selected Indian states". Empirical Economics, 24:641-654.

Koenker, R., and G. Bassett (1978). "Regression Quantiles”. Econometrica, 46, 33-50. 
Koopmans, T. C. (1951). “An Analysis of Production as an Efficient Combination of Activities.” In: T. C. Koopmans (ed), “Activity Analysis of Production and Allocation”. Cowles Commission for Research in Economics, Monograph 13. New York: John-Wiley and Sons, Inc.

Leuthold, J. H. (1991). "Tax shares in developing countries". Journal of Economic Development, v. 35 , p. $175-85$.

Litvack, J., Ahmad, J. and Bird, R. (1998). "Rethinking Decentralization in Developing Countries". Sector Studies Series, The World Bank Washington, D.C.

McCarty, T. and Yaisawarng (1993). "Technical Efficiency in New Jersey School Districts.” In: Fried, H. O, Lovell, C.A K. and Schmidt, S. S. (eds.), "The Measurement of Productive Efficiency". Oxford University Press.

Moesen, W. and Persoon, A. (2002). "Measuring and explaining the productive efficiency of tax offices: a nonparametric best practice frontier approach". Tijdschrift Voor Economie en Management, Vol. 47, No 3, pp.399-416.

Orair, R. C., Alencar, A. A. (2010). "Esforço Fiscal dos Municípios: indicadores de condicionalidade para o sistema de transferências intergovernamentais". XV Prêmio Tesouro Nacional. Brasília: ESAF.

Piancastelli, M. (2001). "Meansuring the tax effort of developed and developing countries. Cross Country Panel Data Analysis - 1985/95". Texto para Discussão, no 818. Rio de Janeiro: IPEA

Reis, E., Blanco, F. A. (1996). “Capacidade Tributária dos Estados Brasileiros - 1970/90”. Economia Brasileira em Perspectiva, v.2. Rio de Janeiro: IPEA.

Rezende, F. (1995). “Federalismo Fiscal: Novo Papel para Estados e Municípios”. Mimeo, IPEA.

Ribeiro, E. P. (1998). "Transferências Intergovernamentais e Esforço Fiscal dos Estados Brasileiros". Anais do XXI Encontro Brasileiro de Econometria.

Ribeiro, E. P., Shikida, C. D. (2000). "Existe Trade-off entre Receitas Próprias e Transferências? O Caso dos Municípios Mineiros". Anais do IX Seminário sobre a Economia Mineira, v. 1., p. 441-462. Belo Horizonte: UFMG - CEDEPLAR.

Sampaio de Sousa, M. C., Stosic, B. D. (2005). "Technical Efficiency of the Brazilian Municipalities: Correcting Nonparametric Frontier Measurements for Outliers". Journal of Productivity Analysis, Springer-Netherlands, v. 24, p. 155-179.

Secretaria do Tesouro Nacional - STN (2005). "Finanças do Brasil - Dados Contábeis dos Municípios -2004”. Brasília: STN.

Simar, L. (2003). "Detecting Outliers in Frontier Models: A Simple Approach”. Journal of Productivity Analysis, v. 20, 391-424.

Simar, L. and P. Wilson (2000). "Statistical Inference in Nonparametric Frontier Models: The State of the Art". Journal of Productivity Analysis, v. 13, 49-78.

(2005). "Statistical inference in nonparametric frontier models: Recent developments and perspectives," In: "The Measurement of Productive Efficiency", ed. H. Fried, C.A.K. Lovell, and S. Schmidt, 2nd ed., Oxford: Oxford University Press.

Thirtle, C., B. Shankar, P. Chitkara, S. Chatterjee and S. Mohanty (2000). "Size Does Matter: Technical and Scale Efficiency in Indian State Jurisdictions." Review of Development Economics, v. 4, 340-352.

United Nations Development Programme - UNDP (2003). "Atlas do Desenvolvimento Humano no Brasil". Brasília: UNPD.

Varsano, R. and Mora, M. (2001). "Fiscal Decentralization and Subnational Fiscal Autonomy in Brazil: Some Facts of the Nineties". Texto Para Discussão No 854. Rio de Janeiro: IPEA.

Vasconcelos, J. R. de, Piancastelli, M., Miranda, R. B. (2006). "Esforço Fiscal dos Estados Brasileiros". Revista Econômica do Nordeste, v. 37, nº 1, p. 7-36. Fortaleza: BNB.

Wilson, P. (1993). "Detecting influential observations in deterministic nonparametric frontiers models". Journal of Business and Economic Statistics, v. 11, 319-323. 
Yu, C. (1998). "The effects of exogenous variables in efficiency measurement - a Monte Carlo study". European Journal of Operational Research, v. 105, 569-580. 